\title{
Reduced Expression of Outer-membrane Proteins in $\beta$-Lactam-resistant Mutants of Enterobacter cloacae
}

\author{
By ROBERT AGGELER, † RUDOLF L. THEN* AND ROBIN GHOSH \\ Pharmaceutical Research Department, F. Hoffmann-La Roche \& Co. Ltd, CH-4002 Basel, \\ Switzerland
}

(Received 9 June 1987)

Two antibiotic-resistant mutants of Enterobacter cloacae (AZT-R and AMA-R), obtained by selection with aztreonam and carumonam, were studied. Both mutants were resistant to $\beta$ lactam antibiotics. In addition, AMA-R was also resistant to chloramphenicol, trimethoprim and brodimoprim, whereas AZT-R was hypersensitive to these compounds. Cytoplasmic and outer membranes of these bacteria were separated by sucrose density gradient centrifugation. Analysis of the outer membranes using SDS-PAGE showed marked changes in the bands corresponding to the porins (between 35 and $40 \mathrm{kDa}$ ). In the two mutants, the $39 \mathrm{kDa}$ band was reduced to approximately $30 \%$ of the wild-type and the $36.5 \mathrm{kDa}$ band was absent. Labelling of the outer membranes with the hydrophobic photolabel 3-(trifluoromethyl)-3-( $m$ - $\left[{ }^{125} \mathrm{I}\right]$ iodophenyl)diazirine ([ $\left.\left.{ }^{125} \mathrm{I}\right] \mathrm{TID}\right)$ enabled the above bands as well as a $28.8 \mathrm{kDa}$ band to be identified as integral membrane proteins, thus supporting the suggestion that they correspond to porins and OmpA protein, respectively. Whereas the changes observed in outer-membrane proteins are assumed to be responsible for resistance to $\beta$-lactam antibiotics, the basis of hypersensitivity of AZT-R to hydrophobic antibiotics remains to be more clearly defined.

\section{INTRODUCTION}

Several mechanisms of resistance to $\beta$-lactams have been proposed involving changes of enzyme specificity (Godfrey et al., 1981), overproduction of target enzymes (Sanders \& Sanders, 1983) and changes of membrane permeability (Lugtenberg \& Peters, 1976; Nikaido, 1985; Nikaido \& Vaara, 1985). Mutations leading to changes of membrane permeability are possibly quite common but are still not well understood. We have chosen Enterobacter cloacae as a model system to examine changes of membrane structure in Gram-negative bacteria responsible for the development of resistance to $\beta$-lactams, because resistant strains are common and are of increasing clinical importance (Sanders \& Sanders, 1983; Werner et al., 1985).

Recently we have obtained two $\beta$-lactam-resistant mutants (designated AZT-R and AMA-R) from the parent $E$. cloacae $908 \mathrm{~S}$ (Then \& Angehrn, 1982, 1986) for which changes of membrane permeability probably constitute the principal mechanism of resistance. Both mutants show a broad resistance to various $\beta$-lactams like ceftriaxone, ceftazidime, aztreonam, carumonam, cefoxitin, cefotetan and others. Additionally, the AMA-R mutant is also resistant to other kinds of antibiotics, e.g. chloramphenicol, trimethoprim or brodimoprim, whereas the AZT-R mutant shows hypersensitivity to these compounds as compared with the wild-type (Then \& Angehrn, 1986). In this study we have characterized in detail the changes in membrane composition observed for the resistant strains.

† Present address: Institute of Molecular Biology, University of Oregon, Eugene, OR 97403, USA.

† Present address: Institut für Pflanzenbiologie und Mikrobiologie, Zollikerstr. 107, CH-8008 Zürich, Switzerland.

Abbreviations: CL, cardiolipin; KDO, 2-keto-3-deoxyoctonate; PE, phosphatidylethanolamine; PG, phosphatidylglycerol; [ ${ }^{25}$ I]TID, 3-(trifluoromethyl)-3-( $m-\left[{ }^{125} I\right]$ iodophenyl)diazirine. 


\section{METHODS}

Bacterial strains. The parent strain, E. cloacae $908 \mathrm{~S}_{\mathrm{wi}}$, as well as the mutants AZT-R and AMA-R have been described recently (Then \& Angehrn, 1986). All strains were kept frozen at $-80^{\circ} \mathrm{C}$ in sterile sheep blood and were stable indefinitely.

Isolation of inner and outer membranes. Cells grown to the stationary phase in tryptic soy broth (Difco) were harvested by centrifugation at $4000 \mathrm{~g}$ for $10 \mathrm{~min}$ at $4{ }^{\circ} \mathrm{C}$, washed twice with $10 \mathrm{~mm}$-sodium phosphate buffer (pH 7.0) and resuspended with $50 \mathrm{~mm}-\mathrm{Tris} / \mathrm{HCl}(\mathrm{pH} 8.0), 1 \mathrm{mM}-\mathrm{MgCl}_{2}, 0.2 \mathrm{~mm}-\mathrm{DTT}$. After addition of deoxyribonuclease, ribonuclease $\left(50 \mu \mathrm{g}\right.$ each $\left.\mathrm{ml}^{-1}\right)$ and phenylmethylsulphonyl fluoride (final concentration $0.1 \mathrm{mM}$ ), the cells were broken by passing three times through a French pressure cell at $1100 \mathrm{~atm}(111 \mathrm{MPa})$. The outer and the cytoplasmic membranes were separated essentially according to Burnell et al. (1980). Unlysed cells were removed by centrifugation at $3000 \mathrm{~g}$ for $20 \mathrm{~min}$ at $4{ }^{\circ} \mathrm{C}$. The supernatant was centrifuged at $17000 \mathrm{~g}$ for $1 \mathrm{~h}$ at $4^{\circ} \mathrm{C}$. At this stage most of the inner membrane should be in the supernatant and the pellet should consist mainly of outer membrane. After resuspension of the outer membrane with $50 \mathrm{~mm}-\mathrm{Tris} / \mathrm{HCl}$ (pH 8.0), $1 \mathrm{mM}-\mathrm{MgCl}_{2}, 0 \cdot 2 \mathrm{mM}-$ DTT, $0.2 \mathrm{M}-\mathrm{KCl}$, the membranes were obtained by centrifugation at $200000 \mathrm{~g}$ for $90 \mathrm{~min}$ at $4^{\circ} \mathrm{C}$. The pellet was resuspended with a syringe in buffer containing no $\mathrm{KCl}$ and layered on top of a sucrose step gradient of $35-55 \%$ (w/w). After 17 h centrifugation at 21000 r.p.m. in a SW 27 rotor (Beckman) at $4^{\circ} \mathrm{C}$, the main band was isolated and diluted with $50 \mathrm{~mm}$-Tris/ $\mathrm{HCl}(\mathrm{pH} 8.0), 1 \mathrm{mM}-\mathrm{MgCl}_{2}, 0.2 \mathrm{~mm}-\mathrm{DTT}$. $\mathrm{KCl}$ was again added to $0.2 \mathrm{M}$ final concentration and the pellet, obtained after centrifugation at $200000 \mathrm{~g}$ for $60 \mathrm{~min}$ at $4{ }^{\circ} \mathrm{C}$, was resuspended in $\mathrm{KCl}$ free buffer. Membranes which were not used the same day were frozen with liquid nitrogen and stored at $-70^{\circ} \mathrm{C}$. The inner membranes were isolated from the supernatant of the $17000 \mathrm{~g}$ centrifugation by the same treatment. The quality of the separation of the two membranes was determined by measuring the NADH-oxidase activity as described by Osborn et al. (1972), by the LPS/protein ratio and by the patterns of the proteins in SDSpolyacrylamide gels.

Hydrophobic photolabelling of outer membranes. To $2 \mathrm{ml}$ outer-membrane suspension $[0.5 \mathrm{mg}$ protein $(\mathrm{ml}$ buffer $\left.)^{-1}\right], 5 \mu \mathrm{l}$ of an ethanolic solution of 3 -(trifluoromethyl)-3-( $m$-[125 I]iodophenyl)diazirine ([125I]TID; $5 \mathrm{mCi} \mathrm{ml}^{-1}, 185 \mathrm{GBq} \mathrm{ml}^{-1}$, Amersham) (Brunner \& Semenza, 1981) was added. After incubation for $10 \mathrm{~min}$ at room temperature, the samples were irradiated by using a Philips TL $40 \mathrm{~W} / 08$ black-light lamp in quartz cuvettes for $10 \mathrm{~min}$ at the same temperature. Nonphotolysed [125I]TID and noncovalently bound photolysis products were removed by washing the membranes twice with buffer containing $0.2 \mathrm{M}-\mathrm{KCl}$. After the second ultracentrifugation at $200000 \mathrm{~g}$ for $90 \mathrm{~min}$ at $4{ }^{\circ} \mathrm{C}$, the pellet was resuspended in $0.3 \mathrm{ml} \mathrm{KCl}$-free buffer. Samples were frozen in liquid nitrogen and stored at $-70^{\circ} \mathrm{C}$. For the analysis of the labelling of outer-membrane components, samples containing $3.5 \times 10^{5}$ c.p.m. were electrophoresed on an SDS-polyacrylamide gel and autoradiographed.

Analytical procedures. Protein was determined according to a modified Lowry procedure (Peterson, 1977), omitting the precipitation step with TCA. To determine the LPS content, the amount of 2-keto-3-deoxyoctonate (KDO) after TCA precipitation of membrane samples (Osborn et al., 1972) containing 0.2-1 mg protein was determined (Karkhanis et al., 1978). As a standard the ammonium salt of KDO from Sigma was used. The lipid content was determined (Chen et al., 1956) after extraction of the isolated membranes (samples containing 1-4 mg protein in $1 \mathrm{ml}$ aqueous solution) according to Bligh \& Dyer (1959), using methylene chloride instead of chloroform. The lipid composition was determined by phosphate analysis of thin-layer chromatography plate scrapings (elution in chloroform/methanol/water, $85: 30: 4$, by vol., on silica gel plates $60 \mathrm{~F}-254$ from Merck). SDS-PAGE was done essentially as described by Laemmli (1970). The protein samples, however, were solubilized in $58 \mathrm{~mm}$-Tris $/ \mathrm{HCl}$ ( $\mathrm{pH} \mathrm{6.8),5 \% (v/v)} \mathrm{glycerol,} 50 \mathrm{~mm}$-DTT, $2 \%(\mathrm{w} / \mathrm{v}) \mathrm{SDS}, 0.02 \%$ bromophenol blue at $95{ }^{\circ} \mathrm{C}$ for $90 \mathrm{~s}$ and applied onto slab gels $(1.5 \mathrm{~mm}$ thick, $20 \mathrm{~cm}$ long). The stacking and the running gel contained 3.75 and $12 \%(w / v)$ acrylamide, respectively, $0 \cdot 16 \% N, N^{\prime}$-methylene-bisacrylamide and $0.1 \%$ SDS. For autoradiography the running gels were dried and exposed on X-ray films from Kodak (X-Omat AR) at $-70{ }^{\circ} \mathrm{C}$.

\section{RESULTS \\ Resistance profile}

The antibiotic susceptibilities of the parent E. cloacae $908 \mathrm{~S}_{w_{1}}$ and the two mutants were obtained by the agar dilution assay (Then \& Angehrn, 1986) (Table 1). Both mutants showed resistance to a variety of $\beta$-lactams but clearly differed from one another in sensitivity to other classes of antibiotics. For instance, AMA-R was also resistant to erythromycin, chloramphenicol, trimethoprim and brodimoprim, whereas AZT-R was hypersensitive to these compounds. The mechanism of resistance against $\beta$-lactam antibiotics in the mutants was due neither to an overproduction of $\beta$-lactamase nor to a decrease in affinity of the penicillin-binding proteins (Then \& Angehrn, 1986). We therefore suspected that the changes in antibiotic susceptibility were connected to alterations in the barrier properties of the cell envelope, probably at the level of the outer membrane. 
Table 1. Minimal inhibitory concentration of various antibiotics for $E$. cloacae $908 S_{w i}$ and the two mutants, $A Z T-R$ and $A M A-R$, respectively

\begin{tabular}{|c|c|c|c|}
\hline \multirow[b]{2}{*}{ Antibiotic } & \multicolumn{3}{|c|}{ Minimal inhibitory concn $\left(\mu \mathrm{g} \mathrm{ml}^{-1}\right)$} \\
\hline & $\mathbf{S}_{\mathrm{wi}}$ & AZT-R & AMA-R \\
\hline Ampicillin & $16 \cdot 0$ & $8 \cdot 0$ & $256 \cdot 0$ \\
\hline Aztreonam & 0.2 & $16 \cdot 0$ & 32.0 \\
\hline Carumonam & 0.1 & 16.0 & 16.0 \\
\hline Cefotetan & 0.4 & $102 \cdot 0$ & $25 \cdot 6$ \\
\hline Ceftazidime & 0.2 & 6.4 & 6.4 \\
\hline Ceftriaxone & 0.1 & $3 \cdot 2$ & 1.6 \\
\hline Lamoxactan & 0.5 & $51 \cdot 0$ & $25 \cdot 6$ \\
\hline Ticarcillin & 1.6 & $204 \cdot 0$ & $409 \cdot 0$ \\
\hline Brodimoprim & 0.8 & $0 \cdot 1$ & $25 \cdot 6$ \\
\hline Ciprofloxacin & 0.06 & 0.06 & 0.5 \\
\hline Chloramphenicol & $6 \cdot 4$ & 1.6 & $25 \cdot 6$ \\
\hline Erythromycin & $204 \cdot 0$ & 25.6 & $204 \cdot 0$ \\
\hline Nalidixic acid & $3 \cdot 2$ & 1.6 & $25 \cdot 6$ \\
\hline Trimethoprim & 0.2 & 0.05 & $3 \cdot 2$ \\
\hline
\end{tabular}

Table 2. Characterization of the inner- and outer-membrane fractions of E. cloacae 908

\begin{tabular}{ccccc} 
Strain & Membrane & $\begin{array}{c}\text { NADH-oxidase } \\
\text { activity* } \\
(\%)\end{array}$ & $\begin{array}{c}\text { Phospholipid/protein ratio } \\
\text { [nmol P (mg protein) }\end{array}$ & $\begin{array}{c}\text { KDO/protein } \\
{[\text { [nmol (mg pro }}\end{array}$ \\
S $_{\mathrm{wi}}$ & CM & 98,99 & 415 & 14 \\
\multirow{2}{*}{ AZT-R } & OM & 2,1 & 265 & 205 \\
& CM & 90,95 & 480 & 20 \\
AMA-R & OM & 10,5 & 295 & 142 \\
& CM & 96,98 & 535 & 23 \\
& OM & 4,2 & 380 & 154
\end{tabular}

$\mathrm{CM}$, cytoplasmic membrane (inner membrane); OM, outer membrane.

- Total activity (mg protein $)^{-1}$ in inner- and outer-membrane fractions is $100 \%[=340$ and $6 \mathrm{nmol}$ NADH oxidized $\min ^{-1}(\mathrm{mg} \text { protein })^{-1}$ for strain $\left.S_{\mathrm{wi}}\right]$; results for two separate preparations are shown.

† Mean of determinations on two separate extractions.

$\ddagger \mathrm{KDO}$ was measured five times.

\section{Separation of cytoplasmic and outer membranes}

The cytoplasmic and outer membranes were separated using sucrose density gradient centrifugation. Initial attempts at membrane separation using the EDTA/lysozyme method of Osborn et al. (1972) as modified by Witholt $e$ t al. (1976) were successful with the wild-type only. Although spheroplasts could be obtained with all three strains, the membranes of the mutants could not be separated by subsequent sucrose density centrifugation.

In contrast, well-separated membrane preparations could be obtained by the method of Schnaitman (1970) (optimized by Burnell et al., 1980), which employs the French pressure cell for initial cell breakage followed by differential and finally sucrose density gradient centrifugation (see Methods). The resuspended pellet from the $17000 \mathrm{~g}$ centrifugation was obtained as a broad white band near the bottom of the centrifuge tube in the final gradient centrifugation step and was designated the H-band (high density). Similarly the supernatant of the $17000 \mathrm{~g}$ step appeared in the upper third of the final gradient and was designated the L-band (low density). For the wild-type, the separation of inner and outer membranes as judged by the specific activity of NADH-oxidase in $\mathrm{H}$ - and L-fractions was very $\operatorname{good}(\mathrm{L} / \mathrm{H}=100)$, and acceptable (though somewhat poorer than for the wild-type) for AMA-R $(L / H=50)$ and AZT$R(L / H=20)$ (Table 2). The distribution of KDO (which occurs exclusively in the LPS of outer membranes) was the reverse of that of NADH-oxidase (i.e. present almost exclusively in the outer membrane), thus confirming the assignment of $\mathrm{L}$ - and $\mathrm{H}$-bands to inner and outer membranes, respectively. Finally, the lipid/protein ratio of the cytoplasmic membrane was consistently higher than that of the outer membrane (Table 2). Similar results have been reported previously for Salmonella typhimurium (Osborn et al., 1972) and Escherichia coli (Burnell et al., 1980; Overath et al., 1975; Schnaitman, 1970). 
Table 3. Phospholipid composition of inner-and outer-membrane fractions of E. cloacae 908

Phospholipids were extracted from membrane fractions after gradient centrifugation as described in the text. The amount of individual phospholipids was determined by phosphate analysis of thin-layer chromatography scrapings. Numerical values are given as a percentage of the total and represent the mean of two separate extractions.

\begin{tabular}{|c|c|c|c|c|c|c|c|}
\hline Strain & Membrane & PE & lyso-PE & $\begin{array}{c}\text { Total } \\
(\mathrm{PE}+\text { lyso-PE })\end{array}$ & PG & CL & $\begin{array}{c}\text { Total } \\
(\mathrm{PG}+\mathrm{CL})\end{array}$ \\
\hline $\mathbf{S}_{w^{\prime \prime}}$ & $\begin{array}{l}\text { CM } \\
\text { OM }\end{array}$ & $\begin{array}{l}73 \\
77\end{array}$ & $\begin{array}{l}0 \cdot 4 \\
9\end{array}$ & $\begin{array}{l}73 \\
86\end{array}$ & $\begin{array}{r}23 \\
6\end{array}$ & $\begin{array}{l}3 \cdot 5 \\
8\end{array}$ & $\begin{array}{l}27 \\
14\end{array}$ \\
\hline AZT-R & $\begin{array}{l}\mathrm{CM} \\
\mathrm{OM}\end{array}$ & $\begin{array}{l}80 \\
76\end{array}$ & $\begin{array}{c}1 \\
10\end{array}$ & $\begin{array}{l}81 \\
86\end{array}$ & $\begin{array}{r}17 \\
5\end{array}$ & $\begin{array}{l}2 \\
9\end{array}$ & $\begin{array}{l}19 \\
14\end{array}$ \\
\hline$A M A-R$ & $\begin{array}{l}\mathrm{CM} \\
\mathrm{OM}\end{array}$ & $\begin{array}{l}79 \\
82\end{array}$ & $\begin{array}{l}1 \\
6\end{array}$ & $\begin{array}{l}80 \\
88\end{array}$ & $\begin{array}{r}17 \\
5\end{array}$ & $\begin{array}{l}3 \\
6\end{array}$ & $\begin{array}{l}20 \\
11\end{array}$ \\
\hline
\end{tabular}

$\mathrm{CM}$, Cytoplasmic membrane (inner membrane); OM, outer membrane.

The phospholipid composition was determined for each of the separated membrane fractions (Table 3). In all three strains phosphatidylethanolamine (PE) was the major phospholipid present in both cytoplasmic and outer membranes. Phosphatidylglycerol (PG) and cardiolipin (CL) were present in both membranes of all strains although cytoplasmic and outer membranes were consistently enriched in PG and CL, respectively. Similar overall phospholipid composition has been reported for $S$. typhimurium (Osborn et al., 1972) and E. coli (Lugtenberg \& van Alphen, 1983) although the specific enrichment of the charged phospholipids in inner and outer membranes, respectively, was somewhat different to that reported here. Significant quantities of lysophosphatidylethanolamine, probably derived from hydrolysis of PE by an endogenous phospholipase (Lugtenberg \& van Alphen, 1983; White et al., 1972), were observed for the outer membranes.

\section{Protein composition of membranes of E. cloacae $908 S_{w i}$ and its mutants}

SDS-PAGE analysis of $\mathrm{H}$ - and $\mathrm{L}$-fractions showed the two membrane populations to be significantly different (Fig. 1). Cytoplasmic membranes contained a broad distribution of proteins (Fig. $1 a-c$ ) whereas the outer membranes contained only four or five major proteins (Fig. $1 d-f$ ). In all three strains the most intense band (probably OmpA protein) had a molecular mass of $28.8 \mathrm{kDa}$ (Fig. $1 d-f$ ). This band was increased by 10 and $40 \%$ (by densitometry, data not shown) relative to that of the wild-type in the AMA-R and AZT-R mutant, respectively. In our experiments, OmpA protein migrated somewhat faster than other OmpA proteins from different Gram-negative bacteria (Beher et al., 1980; Hancock \& Carey, 1979; Lugtenberg \& Peters, 1976). The fast migration of this protein was probably due to the presence of DTT as the reducing agent in the sample buffer (Fig. 2a). When DTT was replaced by 2 -mercaptoethanol (Laemmli, 1970), the $28.8 \mathrm{kDa}$ band could not be detected. Instead, the $37.5 \mathrm{kDa}$ band became much more intense (Fig. $2 b$ ) and the molecular mass was very similar to those described for the heat-modified OmpA proteins (33-35 kDa). We therefore concluded that the $28.8 \mathrm{kDa}$ and the $37.5 \mathrm{kDa}$ band represented two conformational forms of the OmpA protein.

The wild-type strain contained three discrete bands in the porin region $(39,37.5$ and $36.5 \mathrm{kDa}$ ). In the mutants, AZT-R and AMA-R, the relative intensity of the $39 \mathrm{kDa}$ protein was reduced to approximately 25 and $35 \%$ relative to that of the wild-type, respectively. Neither mutant contained the wild-type $36.5 \mathrm{kDa}$ band. The $37.5 \mathrm{kDa}$ band was slightly increased for the AZT-R strain and decreased to approximately $60 \%$ of the wild-type intensity for the AMA$R$ strain. Significant changes were also observed in the 22.7 and $19.6 \mathrm{kDa}$ bands (AZT-R: $22.7 \mathrm{kDa}$ very weak, $19.6 \mathrm{kDa}$ decreased with respect to wild-type; AMA-R: $22.7 \mathrm{kDa}$ very weak, 19.6 kDa increased with respect to wild-type). 

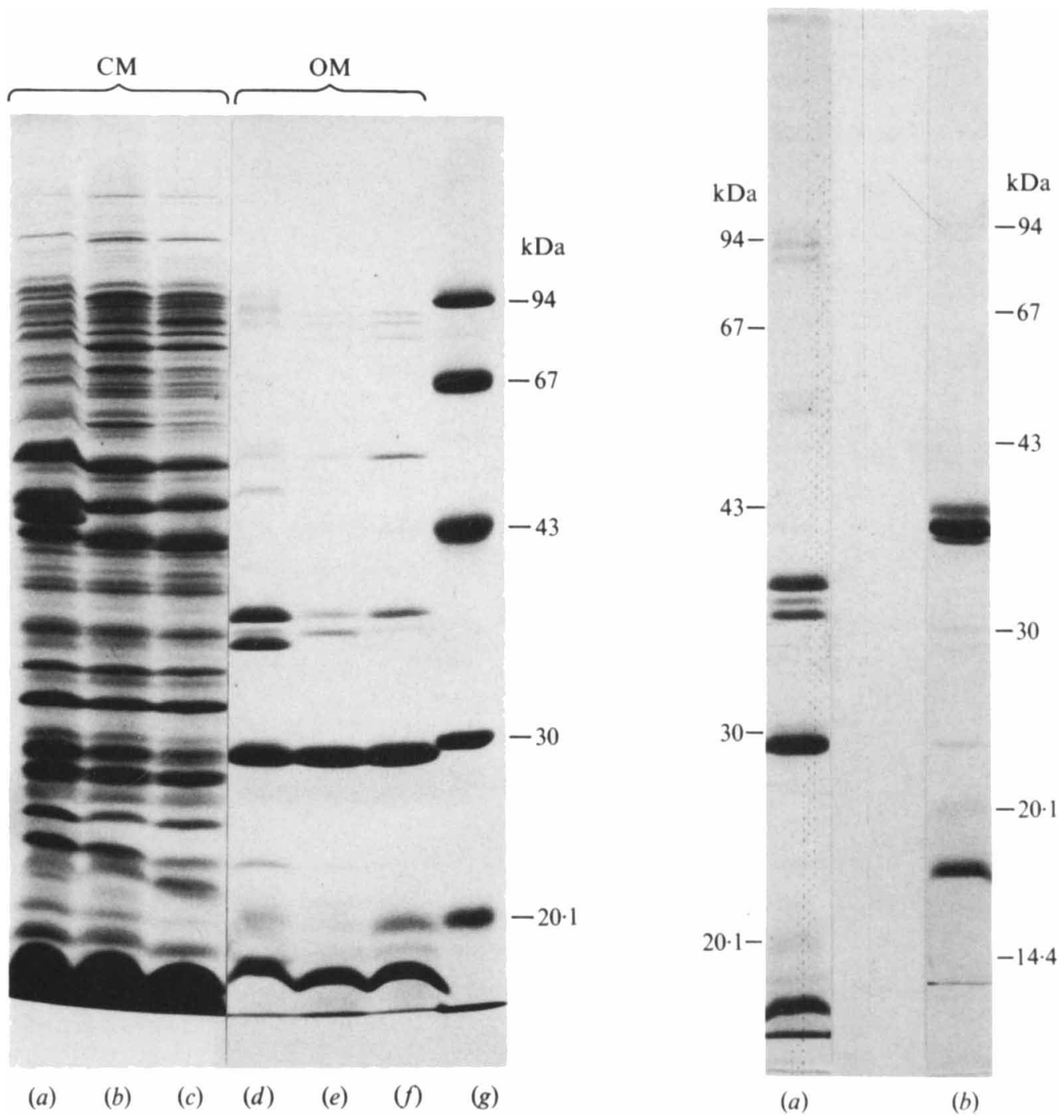

Fig. 1. SDS-PAGE of cytoplasmic (CM) and outer membranes (OM) of E. cloacae 908 . Proteins were analysed on $12 \%$ polyacrylamide gels as described in Methods. Samples $(50 \mu \mathrm{l})$ were applied containing either $200 \mu \mathrm{g}$ cytoplasmic membrane protein (CM) or $100 \mu \mathrm{g}$ outer-membrane protein (OM). The gel was stained in $0.1 \%$ Coomassie blue R-250 (Serva): CM proteins of wild-type $E$. cloacae $908 \mathrm{~S}_{\mathrm{wi}}$ (lane $a$ ), of mutant AZT-R (lane $b$ ) and mutant AMA-R (lane $c$ ); OM proteins of strain $\mathrm{S}_{\mathrm{wi}}$ (lane $d$ ), AZT-R (lane $e$ ) and AMA-R (lane $f$ ). Lane (g), standard proteins (Pharmacia) containing phosphorylase $b(94 \mathrm{kDa}$ ), BSA (67 kDa), ovalbumin (43 kDa), carbonic anhydrase (30 kDa), trypsin inhibitor (20.1 kDa) and $\alpha$ lactalbumin (14.4 kDa).

Fig. 2. SDS-PAGE of outer membranes $(\mathrm{OM})$ of wild-type $E$. cloacae $908 \mathrm{~S}_{\mathrm{wi}}$ using two different reducing agents. Proteins were analysed in $12 \%$ gels by Coomassie blue staining. The reducing agent in the sample buffer was $50 \mathrm{mM}$-DTT (lane $a$ ) and 10\% (w/v) 2-mercaptoethanol (lane $b$ ). Samples $(50 \mu \mathrm{l})$ containing $100 \mu \mathrm{g}$ protein were applied. Molecular mass standards were the same as in Fig. 1.

\section{Hydrophobic photolabelling of outer membranes}

In order to establish whether the above proteins of interest were indeed integral membrane proteins, the isolated outer membranes were labelled with the reagent $\left[{ }^{125} \mathrm{I}\right]$ TID. This recently developed carbene precursor has the advantage of being extremely hydrophobic (the partition 


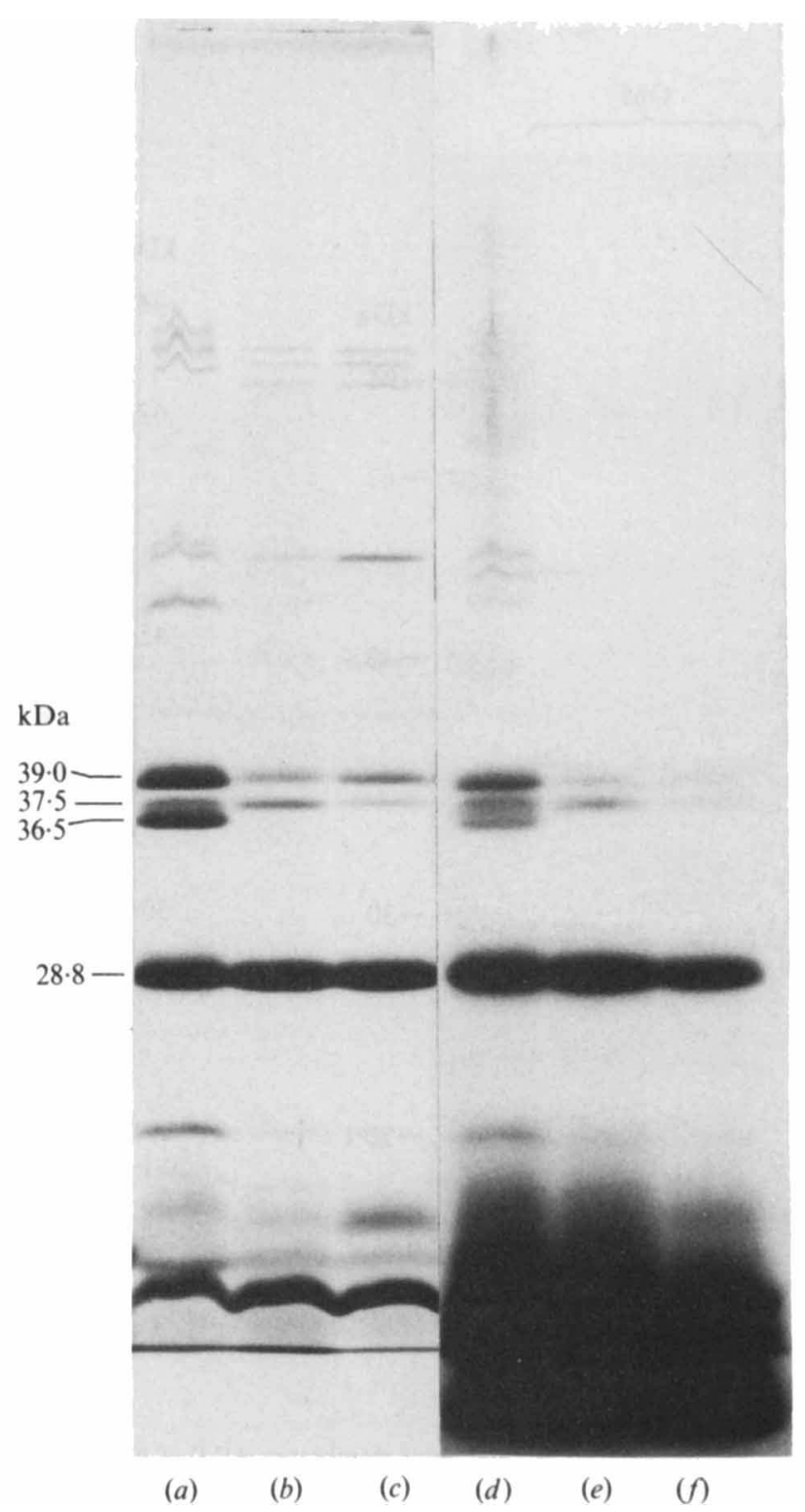

Fig. 3. SDS-PAGE of [ ${ }^{125}$ I]TID-labelled outer membranes from $E$. cloacae 908 . Proteins were anlaysed on $12 \%$ polyacrylamide by Coomassie blue staining (lanes $a-c$ ) and by autoradiography (lanes $d-f$ ). Samples $(63 \mu \mathrm{l})$ containing approximately the same amount of radioactivity were applied. Outermembrane proteins of the wild-type (3.6 $\times 10^{\mathrm{s}}$ c.p.m., $115 \mu \mathrm{g}$ protein, lanes $a$ and $\left.d\right)$, of the mutants AZT-R $\left(3.6 \times 10^{5}\right.$ c.p.m., $150 \mu \mathrm{g}$ protein, lanes $b$ and $\left.e\right)$ and AMA-R $\left(3.6 \times 10^{5}\right.$ c.p.m., $160 \mu \mathrm{g}$ protein, lanes $c$ and $f$ ). Molecular mass standards were the same as in Fig. 1.

coefficient between egg phosphatidylcholine or erythrocyte membranes and aqueous buffer at $25^{\circ} \mathrm{C}$ is approximately $10^{4}$ (Brunner \& Semenza, 1981) and its photogenerated carbene reacts quite nonspecifically. With the relatively weak light source employed, approximately $15 \%$ of the starting radioactivity was incorporated covalently into the membranes within $10 \mathrm{~min}$. Most of the label migrated with the tracking dye or slightly ahead of it (Fig. 3) as a result of reaction with the lipids. Similar observations have been made with erythrocytes (Brunner \& Semenza, 1981) and brush border membranes (Spiess et al., 1982). The autoradiograph (Fig. $3 a-c$ ) shows the 


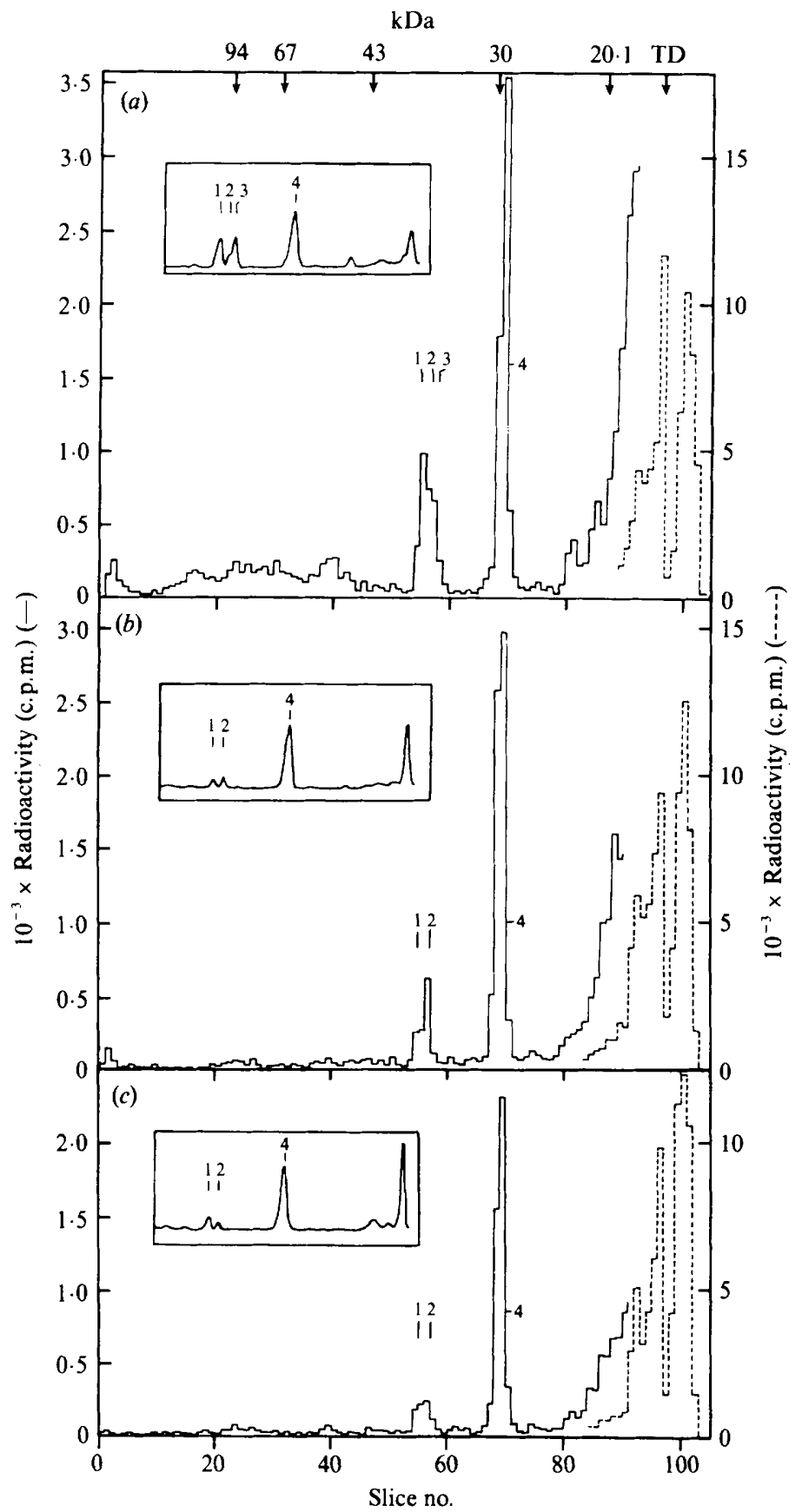

Fig. 4. Distribution of radioactivity in [125I]TID-labelled outer membranes. After electrophoresis of $\left[{ }^{125} \mathrm{I}\right] \mathrm{TID}$-labelled membranes on a $12 \%$ SDS-polyacrylamide gel (cp. legend of Fig. 3), the running gel was dried and the lanes sliced in $2 \mathrm{~mm}$ pieces, which were counted on a $\gamma$-counter (Kontron). Outer membranes of $E$. cloacae $908 \mathrm{~S}_{\mathrm{wi}}(a)$, AZT-R $(b)$ and AMA-R $(c)$. The originally applied amount of radioactivity was $1.82 \times 10^{5}, 1.78 \times 10^{5}$ and $1.65 \times 10^{5}$ c.p.m., respectively. $1,39 \mathrm{kDa}$ band; 2 , $37.5 \mathrm{kDa}$ band; $3,36.5 \mathrm{kDa}$ band; $4,28.8 \mathrm{kDa}$ band. The inserts show the densitometric scans of the gels stained with Coomassie blue. TD, tracking dye. 
Table 4. Percentage distribution of ${ }^{125}$ I-label in the main components of outer membranes

After SDS-PAGE of [125I]TID-labelled outer membranes of the three $E$. cloacae $908 \mathrm{~S}$ strains $\mathrm{S}_{\mathrm{wi}}$, AZT-R and AMA-R as described in the legend of Fig. 3, lanes were cut into $2 \mathrm{~mm}$ pieces, the radioactivity was counted and the relative amounts present in distinct gel regions were calculated.

$\begin{array}{lccc}\begin{array}{c}\text { Gel region } \\ (\mathrm{kDa})\end{array} & \mathrm{S}_{\mathrm{w1}} & \text { AZT-R } & \text { AMA-R } \\ 39 & 1.52 & 0.49 & 0.49 \\ 37.5 & 0.81 & 0.80 & 0.41 \\ 36.5 & 0.99 & 0 & 0 \\ 28.8 & 6.73 & 6.83 & 5.22 \\ \text { Slice nos 80-103* } & 81.12 & 88.57 & 91.59\end{array}$

* Slice no. 1 is at the top of the running gel, 97 at the tracking dye front (cp. Fig. 3).

$28.8 \mathrm{kDa}$ protein and the proteins in the $35-40 \mathrm{kDa}$ region to be the most extensively labelled. After slicing the lanes the $39 \mathrm{kDa}$ band was shown to be specifically reduced in radioactivity to approximately $30 \%$ with respect to that of the wild-type for the AZT-R and AMA-R mutants (Fig. 4, Table 4). This compared well with the decrease in protein observed for this band as determined by Coomassie blue staining. For both mutants the radioactivity in the $36.5 \mathrm{kDa}$ region was only slightly above background and was thus consistent with the results obtained by Coomassie blue staining.

\section{Membrane separation using the detergent Sarkosyl}

SDS-polyacrylamide gels of membranes of the mutants prepared according to the modified (Burnell et al., 1980) procedure of Schnaitman (1970) clearly showed a decrease of the 39 and $36.5 \mathrm{kDa}$ bands. These bands stained very heavily in the wild-type. In contrast, with outer membranes prepared by the often-used Sarkosyl extraction procedure (Filip et al., 1973; Gutmann \& Chabbert, 1984; Sawai et al., 1982; Werner et al., 1985) (data not shown) the wildtype $39 \mathrm{kDa}$ band was weak and not visible at all in the two mutants.

\section{DISCUSSION}

The development of $\beta$-lactam resistance in bacteria has been suggested to arise from a variety of molecular mechanisms: (1) overproduction of $\beta$-lactamases; (2) a reduction in affinity of the penicillin-binding proteins; (3) changes in membrane permeability (see Nikaido, 1985; Nikaido \& Vaara, 1985; Sanders \& Sanders, 1983). In the mutant strains of E. cloacae examined we have excluded (1) and (2) (Then \& Angehrn, 1986), so presumably only the mechanism (3) plays a significant role in the development of resistance. Since the $\beta$-lactam target sites are in the periplasmic space, only changes in permeability of the outer membrane are of importance. We therefore have restricted our studies to the isolation and biochemical characterization of this membrane. Inner and outer membranes of all three strains (wild-type and two mutants) of $E$. cloacae were separated easily using the method of Schnaitman (1970). This method is rapid and allows the isolation of membranes in a native, functional form, thus allowing the determination of important physical and physiological parameters (e.g. enzyme activity, lipid/protein ratio) not obtainable by other techniques such as 'selective' detergent extraction of total membranes for instance with Sarkosyl.

The biochemical characterization of the outer membranes of the three strains used in this study allows exclusion of several potential causes of changes in membrane permeability to $\beta$ lactams. The phospholipid compositions are essentially identical in all three strains (Table 3 ) as are the KDO contents (the KDO content of the wild-type is marginally higher by a factor of $1 \cdot 3$ which is probably not significant), suggesting that these do not constitute the major causal factors of the differing $\beta$-lactam permeabilities observed. We note, however, that in the mutants the total phospholipid (mg protein $)^{-1}$ of the outer membrane is increased, raising the possibility that the distribution of phospholipids between the inner and outer leaflets of the outer 
membrane (since KDO is always confined to the outer leaflet) may play a role in modulating the permeability to antibiotics other than $\beta$-lactams. This idea has been discussed in more detail by Nikaido (1985).

By far the most striking changes are observed in the membrane protein composition in the outer membrane, by the criteria both of Coomassie blue staining and of labelling with the nonspecific photolabel [ ${ }^{125}$ I]TID (Figs 3 and 4). Changes are observed in the 35-40 kDa porin region, the $28.8 \mathrm{kDa}$ region [OmpA protein (Beher et al., 1980; Hancock \& Carey, 1979; Heller, 1978; Lugtenberg \& Peters, 1976)] and also in the low-molecular-mass range. However, only the porins are responsible for building nonspecific membrane channels in the outer membrane (Nikaido et al., 1983; Nikaido \& Rosenberg, 1983; Yoshimura \& Nikaido, 1985) and it seems reasonable to suggest that the changes in this region are responsible almost exclusively for the observed changes in $\beta$-lactam permeability. In the following discussion we restrict ourselves to the 39 and $36.5 \mathrm{kDa}$ proteins as these are the proteins which show the largest changes in the mutants. These two proteins are in fact those that Kaneko et al. (1984) and others (Gutmann \& Chabbert, 1984; Werner et al., 1985; Sawai et al., 1982) have assigned to the porins. The $37.5 \mathrm{kDa}$ band probably corresponds to a nondenaturated OmpA protein conformation (see Results). In both of the mutants examined, one of the two porin bands $(36.5 \mathrm{kDa})$ was completely absent and the other $(39 \mathrm{kDa})$ was reduced with respect to the wild-type. A similar phenomenon has also been observed for different enterobacteria (Gutmann \& Chabbert, 1984; Sawai et al., 1982; Werner et al., 1985). This therefore suggests that porin deletion may be a general mechanism for reducing membrane permeability to $\beta$-lactams. A further mechanism involving a change in porin specificity cannot be excluded but is probably of minor importance in this case. We have confirmed this porin deletion by hydrophobic labelling using the nonspecific photolabel [ ${ }^{125}$ I]TID. This label, which partitions to greater than $99.9 \%$ within the hydrocarbon interior of the membrane, should randomly label all membrane proteins with which it comes into contact. The final specific radioactivity observed reflects the fraction of membrane-embedded proteins and should more accurately reflect changes in protein content than staining by Coomassie blue alone. In the event, the Coomassie blue and [ ${ }^{125}$ I]TID profiles were very similar in the porin region (see Figs 3 and 4) and somewhat different in the highermolecular-mass region. Quantification of the specific radioactivity shows that both mutant strains contained only one-third of the $39 \mathrm{kDa}$ porin as compared to the wild-type (Table 4). This suggests that not only deletion of a porin but also reduction in the number of porin molecules may play a role in determining the level of resistance.

Finally, the mutant strains of $E$. cloacae differ dramatically in their susceptibility to antibiotics not related to $\beta$-lactams (Table 1). At least some of these antibiotics are hydrophobic in character, which may be a prerequisite to their ability to penetrate the inner membrane in order to reach the target site (e.g. trimethoprim, chloramphenicol). In these cases the mechanisms responsible for antibiotic resistance or hypersensitivity are probably more complex than those described above, possibly involving changes in lipid permeability (see Nikaido, 1985). In this context, the changes in the KDO/phospholipid ratio described above may be of significance but at present we have no satisfactory explanation for the unusual susceptibility pattern of strain AZT-R.

We thank Dr P. Angehrn for providing the mutant strains, Mr M. Methali for assistance with preliminary experiments and Mrs I. Kohl for technical assistance.

\section{REFERENCES}

Beher, M. G., Schnaitman, C. A. \& Pugsley, A. P. (1980). Major heat-modifiable outer membrane protein in Gram-negative bacteria: comparison with the OmpA protein of Escherichia coli. Journal of Bacteriology 143, 906-913.

BLIGH, E. G. \& DYER, W. J. (1959). A rapid method of total lipid extraction and purification. Canadian Journal of Biochemistry and Physiology 37, 911-917.
Brunner, J. \& Semenza, G. (1981). Selective labelling of the hydrophobic core of membranes with 3(trifluoromethyl)-3-( $m-\left[{ }^{125} I\right]$ iodophenyl)diazirine, a carbene-generating reagent. Biochemistry 20, 71747182.

BurNell, E., van Alphen, L., VerkleiJ, A., DE KruisfF, B. \& LugtenberG, B. (1980). ${ }^{31}$ P nuclear magnetic resonance and freeze-fracture electron 
microscopy studies on Escherichia coli. III. The outer membrane. Biochimica et biophysica acta 597, 518532.

Chen, P. S., Toribara, T. Y., JR \& Warner, H. (1956). Microdetermination of phosphorus. Analytical Chemistry 28, 1756-1758.

Filip, C., Fletscher, G., Wulff, J. L. \& Earhardt, C. F. (1973). Solubilization of the cytoplasmic membrane of Escherichia coli by the ionic detergent sodium-lauryl sarcosinate. Journal of Bacteriology 115, 717-722.

Godfrey, A. J., Bryan, L. E. \& Rabin, H. R. (1981). $\beta$-Lactam resistant Pseudomonas aeruginosa with modified pencillin-binding proteins emerging during cystic fibrosis treatment. Antimicrobial Agents and Chemotherapy 19, 705-711.

Gutmann, L. \& Chabbert, Y. A. (1984). Different mechanisms of resistance to latamoxef (moxalactam) in Serratia marcescens. Journal of Antimicrobial Chemotherapy 13, 15-22.

HancoCk, R. E. W. \& Carey, A. M. (1979). Outer membrane of Pseudomonas aeruginosa: heat- and 2mercaptoethanol-modifiable proteins. Journal of Bacteriology 140, 902-910.

HeLler, K. B. (1978). Apparent molecular weights of a heat-modifiable protein from the outer membrane of Escherichia coli in gels with different acrylamide concentrations. Journal of Bacteriology 134, 1181 1183.

Kaneko, M., Yamaguchi, A. \& Sawai, T. (1984). Purification and characterization of two kinds of porins from the Enterobacter cloacae outer membrane. Joumal of Bacteriology 158, 1179-1181.

Karkhanis, Y. D., Zeltner, J. Y., Jackson, J. J. \& CARLO, D. J. (1978). A new and improved microassay to determine 2-keto-3-deoxyoctonate in lipopolysaccharide of Gram-negative bacteria. Analytical Biochemistry 85, 595-601.

LAEMMLI, U. K. (1970). Cleavage of structural proteins during the assembly of the head of bacteriophage $\mathrm{T} 4$. Nature, London 227, 680-685.

LUGtenberg, B. \& VAN Alphen, L. (1983). Molecular architecture and functioning of the outer membrane of Escherichia coli and other Gram-negative bacteria. Biochimica et biophysica acta 737, 51-115.

Lugtenberg, E. J. J. \& Peters, R. (1976). Distribution of lipids in cytoplasmic and outer membranes of Escherichia coli K12. Biochimica et biophysica acta 441, 38-47.

NIKaIDO, H. (1985). Role of permeability barriers in resistance to $\beta$-lactam antibiotics. Pharmacology and Therapeutics 27, 197-231.

Nikaido, H. \& Rosenberg, E. Y. (1983). Porin channels in Escherichia coli: studies with liposomes reconstituted from purified proteins. Journal of Bacteriology 153, 241-252.

Nikaido, H. \& VaAra, M. (1985). Molecular basis of bacterial outer membrane permeability. Microbiological Reviews 49, 1-32.

Nikaido, H., Rosenberg, E. Y. \& Foulds, J. (1983). Porin channels in Escherichia coli: studies with $\beta$ - lactams in intact cells. Journal of Bacteriology 153, 232-240.

Osborn, M. J., Gander, J. E., Parisi, E. \& Carson, J. (1972). Mechanism of assembly of the outer membrane of Salmonella typhimurium. Journal of Biological Chemistry 247, 3962-3972.

Overath, P., Brenner, M., Gulik-Krzywicki, T., SheChTER, E. \& LeTEllier, L. (1975). Lipid transitions in cytoplasmic and outer membranes of Escherichia coli. Biochimica et biophysica acta 389, 358-369.

Peterson, G. L. (1977). A simplification of the protein assay method of Lowry et al. which is more generally applicable. Analytical Biochemistry 83, 346-356.

SANDERS, C. C. \& SANDERS, W. E., JR (1983). Emergence of resistance during therapy with the newer $\beta$-lactam antibiotics: role of inducible $\beta$ lactamases and implications for the future. Reviews of Infectious Diseases 5, 639-648.

Sawal, T., Hiruma, R., Kawana, N., Kaneko, M., TANiYasu, F. \& Inami, A. (1982). Outer membrane permeation of $\beta$-lactam antibiotics in Escherichia coli, Proteus mirabilis and Enterobacter cloacae. Antimicrobial Agents and Chemotherapy 22, 585-592.

Schnaltman, C. A. (1970). Protein composition of the cell wall cytoplasmic membrane of Escherichia coli. Journal of Bacteriology 104, 890-901.

Spiess, M., Brunner, J. \& Semenza, G. (1982). Hydrophobic labeling, isolation, and partial characterization of the $\mathrm{NH}_{2}$-terminal membranous segment of sucrase-isomaltase complex. Journal of Biological Chemistry 257, 2370-2377.

Then, R. L. \& ANGeHRN, P. (1982). Trapping of nonhydrolyzable cephalosporins by cephalosporinases in Enterobacter cloacae and Pseudomonas aeruginosa as a possible resistance mechanism. Antimicrobial Agents and Chemotherapy 21, 711-717.

Then, R. L. \& ANGEHRN, P. (1986). Multiply resistant mutants of Enterobacter cloacae selected by $\beta$-lactam antibiotics. Antimicrobial Agents and Chemotherapy 30, 684-688.

Werner, V., Sanders, C. C., Sanders, W. E., JR. \& Goering, R. V. (1985). Role of $\beta$-lactamases and outer membrane proteins in multiple $\beta$-lactam resistance of Enterobacter cloacae. Antimicrobial Agents and Chemotherapy 27, 455-459.

White, D. A., Lennarz, W. J. \& Schnaitman, C. A. (1972). Distribution of lipids in the wall and cytoplasmic membrane subfractions of the cell envelope in Escherichia coli. Journal of Bacterialogy 109, 686-690.

Witholt, B., BoEkhout, M., BRock, M., Kingma, J., van HeErikhuizen, H. \& DE Leis, L. (1976). An efficient and reproducible procedure for the formation of spheroplasts from variously grown Escherichia coli. Analytical Biochemistry 74, 160170.

Yoshimura, F. \& Nikaido, H. (1985). Diffusion of $\beta$ lactam antibiotics through the porin channels of Escherichia coli K-12. Antimicrobial Agents and Chemotherapy 27, 84-92. 